\author{
Pawee BlaJer ${ }^{1}$
}

\title{
Gospodarstwa rodzinne w USA - status, znaczenie i aktualne problemy
}

\section{Uwagi wstępne}

Gospodarstwo rodzinne (family farm) do dnia dzisiejszego stanowi narodowy ideał w Stanach Zjednoczonych Ameryki. ${ }^{2}$ Jak się wydaje, przyczyn tego stanu rzeczy należy poszukiwać w głębokim sentymencie, jakim współcześni Amerykanie otaczają tę instytucję, jak i rolnictwo w ogólności, pomimo iż współcześnie zaledwie około $2 \%$ społeczeństwa amerykańskiego jest bezpośrednio zaangażowane w prowadzenie działalności rolniczej. ${ }^{3}$ Niemniej należy pamiętać, że korzenie bardzo wielu współczesnych Amerykanów sięgają idealizowanej ,,wiejskiej Ameryki”, a obecna w społeczeństwie nostalgia za „starym, dobrym życiem na farmie” jest na tyle mocna, że pozwala ona niektórym badaczom na formułowanie tezy o typowo amerykańskiej „,wiejskiej etyce w zindustrializowanym społeczeństwie”. ${ }^{4}$

Celem niniejszego opracowania jest zatem przedstawienie amerykańskiej koncepcji gospodarstwa rodzinnego oraz zweryfikowanie tezy o jego zasadniczym znaczeniu dla rolnictwa w USA. Cel ten realizować ma przyjęta konstrukcja pracy. W ramach pierwszej części omówiono genezę koncepcji gospodarstwa rodzinnego w Ameryce, a także jego współczesne definicje. W części drugiej scharakteryzowano znaczenie gospodarstw rodzinnych w świetle poglądów doktryny oraz rolę, jaką te jednostki produkcyjne odgrywają w rolnictwie amerykańskim. Część trzecia

$1 \quad$ Uniwersytet Jagielloński.

2 J.B. Wadley, Agriculture and Farm Law, [w:] Thompson on Real Property, D.A. Thomas (red.), t. 6, Newark-San Francisco 2003, s. 87.

3 T. Dowell, Daddy won't sell the Farm: Drafting Right to Farm Statutes to Protect Small Family Producers, „San Joaquin Agricultural Law Review" 2008-2009, nr 18, s. 127.

4 Por. D.A. Myers, Farmland Preservation in a Democratic Society: Looking to the Future, „Agricultural Law Journal” 1982, nr 3, s. 605-607; S.C. Bahls, Preservation of Family Farms - the Way Ahead, „Drake Law Review” 1997, nr 45, s. 323. Głębokie przywiązanie Amerykanów do tradycji wiejskiego życia było zresztą jednym z czynników, które doprowadziły do odczuwalnej już w latach 50., a szczególnie nasilającej się od lat 70. XX wieku, powrotnej migracji ludności miejskiej w rejony podmiejskie i wiejskie. Niemniej osoby „wracające na wieś” tylko zupełnie wyjątkowo podejmują prowadzenie działalności rolniczej; z reguły poszukują wyłącznie atrakcyjnych miejsc do zamieszkania na wsi, swoją aktywność zawodową nadal przejawiając przede wszystkim w rejonach zurbanizowanych. Por. T. Dowell, Daddy won't sell the Farm..., op. cit., s. 128-129. 
pracy poświęcona jest najważniejszym problemom, przed jakimi obecnie stoją osoby prowadzące gospodarstwa rodzinne; część czwarta określa natomiast metody publicznego wsparcia udzielanego gospodarstwom rodzinnym przez władze stanowe i federalne.

\section{Koncepcja gospodarstwa rodzinnego w USA}

Korzenie amerykańskiej koncepcji gospodarstwa rodzinnego sięgają końca XVIII wieku, kiedy to Thomas Jefferson, zasłużony polityk i trzeci prezydent USA, opracował pierwszą definicję tego pojęcia. ${ }^{5}$ Jego zdaniem gospodarstwo rodzinne miało spełniać trzy zasadnicze kryteria:

- gospodarstwo powinno być samowystarczalne - tzn. prowadzący je farmer powinien jak najmniej sprzedawać i kupować,

- farmer powinien osobiście $\mathrm{w}$ nim pracować oraz samodzielnie nim zarządzać,

- farmer powinien być właścicielem gruntów wchodzących w skład gospodarstwa.

W konsekwencji, gospodarstwo rodzinne - jako najbardziej pożądana forma prowadzenia działalności rolniczej w Ameryce - miało posiadać charakter niekomercyjny, a prowadzący je rolnik miał być moralnie zdrowy, niezależny politycznie i wolny od wymagań rynku. ${ }^{6}$ Definicja ta nie uwzględniała natomiast związków rodzinnych pomiędzy osobami prowadzącymi gospodarstwo. ${ }^{7}$

Stworzony przez Jeffersona ideał gospodarstwa rodzinnego miał odtąd przez długie lata wywierać przemożny wpływ na sposób rozumienia tej instytucji zarówno przez samych Amerykanów, przedstawicieli amerykańskiej doktryny agrarystycznej, jak również federalne i stanowe agendy zajmujące się rolnictwem. ${ }^{8}$ Teoretycznie, główne założenia tej koncepcji nadal wpływają na współczesną amerykańską politykę rolną, w ramach której gospodarstwo rodzinne formalnie stanowi podsta-

J.B. Wadley, Small Farms: The USDA, Rural Communities and Urban Pressures, „Washburn Law Journal” 19811982, nr 21, s. 479

6 J.B. Wadley, Small Farms..., op. cit., s. 481.

7 Th. Jefferson dążył przede wszystkim do upowszechnienia gospodarstw rodzinnych jako preferowanej formy gospodarowania w USA. W dużej liczbie małych gospodarstw rodzinnych widział on bowiem szansę na zwiększenie zaangażowania społecznego w sprawy publiczne, z uwagi na fakt, iż w owym okresie czynne i bierne prawo wyborcze uzależnione było od dysponowania tytułem prawnym do ziemi. Por. J.M. Jacobson, Development of American Political Thought, A Documentary History, New York 1932, s. 274.

$\mathrm{Na}$ koncepcji Jeffersona opierał się między innymi Kongres uchwalając w 1862 roku ustawę o gospodarstwach rolnych (Homestead Act), proklamującą tworzenie gospodarstw rodzinnych podstawowym celem federalnej polityki władania ziemią w USA; w owym czasie w gospodarstwie rodzinnym nadal widziano narzędzie zapewniające licznym imigrantom dostęp do własności amerykańskiej ziemi. Por. J.B. Wadley, Agriculture and Farm Law..., op. cit., s. 90 . 
wę ustroju rolnego w USA. Świadczyć może o tym chociażby treść $§ 2266^{9}$ Kodeksu Stanów Zjednoczonych (US Code), tj. skonsolidowanego zbioru prawa federalnego obowiązującego w USA, ${ }^{10} \mathrm{w}$ ramach którego Kongres potwierdza historyczną politykę Stanów Zjednoczonych zmierzającą do wzmocnienia gospodarstw rodzinnych, zauważając, że ich zachowanie jest niezbędne do utrzymania narodowego dobrobytu, jak również konkurencyjnej produkcji i bezpieczeństwa dostaw żywności. W przepisie tym Kongres wskazuje ponadto, że ekspansja rolnictwa pozbawionego rodzinnego charakteru, w tym w szczególności gospodarstw prowadzonych przez korporacje, jest szkodliwa dla dobrobytu narodowego. ${ }^{11}$

Urzeczywistnienie deklarowanej przez Kongres zasady ochrony i wsparcia gospodarstw rodzinnych napotyka jednak istotne problemy w praktyce. W dużej mierze są one skutkiem braku jednolitej współczesnej definicji gospodarstwa rodzinnego w USA. Zarysowana wyżej koncepcja Th. Jeffersona, pomimo szacunku, jakim nadal jest otaczana, nie przystaje już bowiem do współczesnej rzeczywistości społeczno-gospodarczej. Jej poważny kryzys zapoczątkowany został w okresie Wielkiej Depresji lat trzydziestych XX wieku, a pogłębił go dodatkowo proces industrializacji rolnictwa po II Wojnie Światowej. W efekcie wymienionych przemian gospodarczych wiele małych gospodarstw rodzinnych zostało wyeliminowanych $\mathrm{z}$ rynku, a ich miejsce zajęły wielkie gospodarstwa industrialne (tzw. agribusiness), które stały się ponadto głównym beneficjentem publicznego wsparcia rolnictwa. ${ }^{12}$ Jednakże do pojęcia gospodarstwa rodzinnego nadal często odwołują się instytucje stanowe i federalne, przedstawiciele doktryny agrarystycznej, a także organizacje pozarządowe. Niemniej kryteria służące indywidualizacji gospodarstwa rodzinnego na płaszczyźnie różnych aktów prawnych, dokumentów i opracowań doktrynalnych charakteryzują się istotną heterogenicznością, która z jednej strony zapewnia elastyczność tego pojęcia, z drugiej jednak uniemożliwia precyzyjne określenie, co należy pod nim rozumieć.

Analizę różnorodnych koncepcji i definicji pojęcia gospodarstwa rodzinnego funkcjonujących w USA rozpocząć można od prób zdefiniowania tego pojęcia podej-

9 § 2266 ujęty został w ramach rozdziału 55 (Departament Rolnictwa) kodeksu; rozdział ten objęty jest z kolei tytułem 7 (Rolnictwo).

10 Jego treść dostępna jest pod adresem: http://uscode.house.gov/

11 W konsekwencji programy wsparcia rolnictwa, zdaniem Kongresu, chociaż nie powinny ograniczać się wyłącznie do gospodarstw rodzinnych, nie mogą jednocześnie stwarzać warunków, które stawiałyby te gospodarstwa w niekorzystnej sytuacji ekonomicznej. Na temat współczesnego podejścia Kongresu do problematyki gospodarstw rodzinnych oraz ich sytuacji w ramach ewoluującego rolnictwa w USA - por. w szczególności: N. Hamilton, Tending the Seeds: The Emergence of a New Agriculture in the United States, „Drake Journal of Agricultural Law” 1996, nr 1, s. 7 i n.; idem, Plowing New Ground: Emerging Issues in a Changing Agriculture, „Drake Journal of Agricultural Law" 1997, nr 2, s. 181 i n.; idem, Reaping What We Have Sown: Public Policy Consequences of Agricultural Industrialization and the Legal Implications of the Changing Production System, „Drake Law Review” 1997, nr 45, s. 361.

12 Por. M.J. Wender, Goodbye Family Farms and Hello Agribusiness: The Story of How Agricultural Policy is Destroying the Family Farm and the Environment, „Villanova Environmental Law Journal” 2011, nr 22, s. 146-147; W.S. Eubanks, The Sustainable Farm Bill: A Proposal for Permanent Environmental Change, Environmental Law Institute, News \& Analysis, 2009, artykuł dostępny pod adresem: http://ssrn.com/abstract=1410800 
mowanych w literaturze agrarystycznej oraz $\mathrm{w}$ dokumentach publikowanych przez organizacje pozarządowe. Na szczególną uwagę w tym względzie zasługuje holistyczna koncepcja gospodarstwa rodzinnego sformułowana przez M. Strange'a ponad ćwierć wieku temu. ${ }^{13} \mathrm{M}$. Strange opisał model rolnictwa oparty o gospodarstwa rodzinne jako system co do zasady właścicielski, skoncentrowany na rodzinie rolniczej, zachowujący harmonię pomiędzy postępem technicznym i gospodarczym a ochroną środowiska naturalnego (harmonię z naturą), przede wszystkim poprzez zdywersyfikowanie produkcji i zachowanie zasobów. System ten charakteryzuje się ponadto rozproszoną własnością gruntów, równym dostępem do rynków i postrzeganiem rolnictwa jako stylu życia. Cytowane szerokie ujęcie gospodarstwa rodzinnego uwzględnia zatem znacznie więcej czynników niż tylko więzy rodzinne łączące osoby prowadzące gospodarstwo oraz udział rodziny rolniczej w ogóle prac gospodarskich.

Węższą i nieco bardziej szczegółową definicję gospodarstwa rodzinnego opracował D.A. Sumner w latach 80 . XX wieku. ${ }^{14}$ Jego zdaniem, za takie gospodarstwo należy uznać gospodarstwo, w ramach którego:

- działalność rolnicza stanowi główne zajęcie osoby je prowadzącej lub też stanowi główne źródło utrzymania rodziny rolniczej,

- osoba prowadząca gospodarstwo poświęca temu zajęciu przynajmniej połowę swojego czasu pracy,

- działalność rolnicza wykonywana jest wspólnie przez nie więcej niż trzy rodziny rolnicze.

Swoją własną, elastyczną definicję gospodarstwa rodzinnego opracowała również zrzeszająca rolników z Nebraski organizacja pozarządowa - Center of Rural Affairs. ${ }^{15} \mathrm{~W}$ opinii tej organizacji pod pojęciem gospodarstwa rodzinnego należy rozumieć gospodarstwo, którym zarządza rodzina rolnicza, świadcząca w nim jednocześnie większość pracy oraz którego składniki stanowią przynajmniej częściowo własność tej rodziny. Oparcie rolnictwa amerykańskiego o tego typu gospodarstwa pozwoliłoby na:

- pełniejsze wykorzystanie owoców swej pracy przez osoby pracujące w gospodarstwach rolnych,

- zapewnienie dostępu do rolnictwa nowym osobom, także w przypadku gdy nie dysponują one istotnymi środkami finansowymi,

14 D.A. Sumner, Farm Programs and Structural Issues, [w:] US Agricultural Policy: The 1985 Farm Legislation, B.L. Gardner (red.), Washington 1985, s. 286. 
- zachowanie zadowalającej liczby gospodarstw rolnych przyczyniających się do utrzymania zdrowych społeczności wiejskich,

- powstrzymanie trendu w kierunku konsolidacji gospodarstw rolnych i tworzenia wielkich jednostek produkcyjnych, wypierających z rynku mniejszych konkurentów.

Istotniejsze znaczenie praktyczne od wyżej przytoczonych koncepcji doktrynalnych posiadają definicje gospodarstwa rodzinnego funkcjonujące na płaszczyźnie regulacji prawnych; zarówno stanowych, jak i federalnych. Tytułem przykładu należy podkreślić, że zróżnicowanymi definicjami tego pojęcia posługują się niektóre statuty stanowe. W Illinois funkcjonuje stosunkowo szerokie ujęcie gospodarstwa rodzinnego, zgodnie z którym family farmer to rezydent tego stanu, będący właścicielem lub dzierżawcą ziemi w Illinois, wykorzystywanej na cele prowadzenia działalności rolniczej. ${ }^{16}$ Definicja ta abstrahuje zatem od rozmiarów gospodarstwa, jego struktury lub zaangażowania rodziny rolniczej w jego prowadzenie. ${ }^{17} \mathrm{~W}$ Iowa - innym stanie posługującym się definicją gospodarstwa rodzinnego - jego rozumienie jest znacznie bardziej zawężone; za gospodarstwo rodzinne uznaje się jednostkę produkcyjną, w ramach której spokrewnieni ze sobą właściciele prowadzą działalność rolniczą, osiągając z niej co najmniej $60 \%$ dochodów na przestrzeni ostatnich trzech lat. ${ }^{18}$ Tym samym definicja ta wyklucza dzierżawców z kategorii osób prowadzących gospodarstwa rodzinne, kładąc jednocześnie nacisk na więzy rodzinne pomiędzy nimi oraz uznając, że family farms mogą być także prowadzone przez nierezydentów.

Jeszcze inaczej do problematyki gospodarstw rodzinnych podchodzą konstytucje stanów Nebraska i Południowa Dakota. Przewidują one sytuacje, w których gospodarstwa rodzinne mogą zachować swój status, pomimo iż prowadzone są przez osoby prawne (family farm or ranch corporations). By tak się stało, osoby prawne prowadzące gospodarstwo rodzinne muszą jednak spełniać ściśle określone kryteria, tj. większościowy pakiet akcji lub udziałów powinien przysługiwać osobom blisko ze sobą spokrewnionym, z których przynajmniej jedna powinna zamieszkiwać w gospodarstwie i angażować się w codzienną pracę oraz zarządzanie gospodar-

Illinois Compiled Statutes, rozdz. 55 (Agriculture), statut 57 (Illinois Family Farmer Support Act), sekcja 5; tekst aktu dostępny pod adresem: http://www.ilga.gov/legislation/ilcs/ilcs.asp

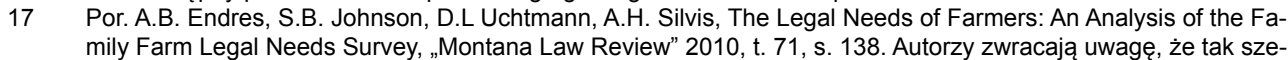
rokie ujęcie gospodarstwa rodzinnego w Illinois powoduje, że praktycznie wszystkie grunty będące własnością lub dzierżawione przez rezydentów tego stanu i wykorzystywane na cele prowadzenia działalności rolniczej mieszczą się w zakresie pojęcia "gospodarstwo rodzinne”. ic?f=templates\&fn=default.htm 
stwem. Pozostali wspólnicy lub akcjonariusze powinni ponadto zamieszkiwać na terenie stanu, w którym położone jest gospodarstwo rodzinne. ${ }^{19}$

Gospodarstwa rodzinne definiowane są również na płaszczyźnie regulacji federalnych. Już z przytoczonej wyżej deklaracji Kongresu zawartej w Kodeksie Stanów Zjednoczonych można wysnuć wniosek, że instytucja ta rozumie pod pojęciem gospodarstwa rodzinnego wszystkie gospodarstwa z wyjątkiem tych prowadzonych przez wielkie korporacje pozbawione rodzinnego charakteru. ${ }^{20}$

W praktyce za sposób rozumienia gospodarstwa rodzinnego $\mathrm{w}$ federalnych aktach prawnych i programach pomocowych odpowiedzialny jest Departament Rolnictwa Stanów Zjednoczonych (USDA - United States Department of Agriculture), jako urząd formalnie zaangażowany w udzielanie wsparcia takim gospodarstwom. Kryteria te na przestrzeni lat funkcjonowania Departamentu ulegały modyfikacjom. Współcześnie USDA posługuje się definicją gospodarstwa rodzinnego zakładającą, iż za takie gospodarstwo należy uważać formę działalności rolniczej, w ramach której ryzyko gospodarcze spoczywa na prowadzącym gospodarstwo rolniku, wykonującym wraz z rodziną większość prac w gospodarstwie, jak również podejmującym wraz z rodziną większość czynności zarządczych. ${ }^{21}$

Przytoczona ogólna definicja gospodarstwa rodzinnego rozwijana jest także na płaszczyźnie konkretnych programów pomocowych. Tytułem przykładu można wymienić roboczą definicję wykorzystywaną przez USDA Farm Service Agency (FSA), na potrzeby zarządzanego przez tę agencję specjalnego programu tanich kredytów udzielanych gospodarstwom rodzinnym. Zgodnie z tą definicją gospodarstwem rodzinnym jest gospodarstwo, w którym:

- ilość wytwarzanych produktów rolnych pozwala uznać, że gospodarstwo ma charakter produkcyjny, a nie zaspokaja tylko potrzeb mieszkaniowych,

- większość bieżących decyzji produkcyjnych i wszelkie decyzje gospodarcze o charakterze strategicznym podejmowane są przez kredytobiorcę lub kredytobiorcę i osoby złączone z nim węzłem pokrewieństwa, małżeństwa lub powinowactwa,

- zasadnicza ilość pracy w gospodarstwie świadczona jest przez kredytobiorcę lub kredytobiorcę i osoby złączone z nim węzłem pokrewieństwa, małżeństwa lub powinowactwa, praca najemna w pełnym wymiarze ma charakter wyłącznie uzupełniający względem pracy świadczonej przez rodzinę rolniczą,

Por. Nebraska Constitution, art. XII, § 8, tekst aktu dostępny pod adresem: http://nebraskalegislature.gov/laws/ browse-constitution.php ; South Carolina Constitution, art. XVII, § 22, tekst aktu dostępny pod adresem: http:// www.scstatehouse.gov/scconstitution/scconst.php

20 D.A. Sumner, Farm Programs and Structural Issues..., op. cit., s. 286.

21 Por. J.B. Wadley, Agriculture and Farm Law..., op. cit., s. 90; A.B. Endres, S.B. Johnson, D.L Uchtmann, A.H. Silvis, The Legal Needs of Farmers:..., op. cit., s. 137. 
- praca najemna o charakterze sezonowym jest wykorzystywana w rozsądnym zakresie w okresie szczególnie intensywnych prac gospodarskich. ${ }^{22}$

Powołane definicje abstrahują tym samym od takich kryteriów, jak rodzaj praw przysługujących rolnikowi do środków produkcji, rozmiary sprzedaży dokonywanej przez rolnika lub czas pracy angażowanego w działalność rolniczą i dochód z niej uzyskiwany. Podkreślają one znaczenie, jakie dla funkcjonowania gospodarstwa posiada praca rodziny rolniczej oraz zwracają uwagę na ryzyko związane z prowadzoną działalnością ponoszone przez rodzinę rolniczą.

Teoretycznie zatem współczesna definicja gospodarstwa rodzinnego wykorzystywana przez USDA nie ma charakteru dyskryminującego małe gospodarstwa rodzinne. $\mathrm{Z}$ drugiej jednak strony jest ona stosunkowo szeroka; pozwala zakwalifikować większość gospodarstw w USA do grupy gospodarstw rodzinnych, w tym także gospodarstwa największe i najbardziej produktywne. ${ }^{23}$ Jest ona również na tyle elastyczna, że pozwala USDA na jej reinterpretację w zależności od konkretnych programów wdrażanych przez tę instytucję i celów, jakie mają one realizować, a nawet na tworzenie roboczych definicji odbiegających zasadniczo od oficjalnej definicji gospodarstwa rodzinnego. Na płaszczyźnie konkretnych programów subwencje kierowane są zatem najczęściej do dużych gospodarstw charakteryzujących się znaczną produktywnością; mniejszym jednostkom produkcyjnym tego wsparcia się odmawia. Ten fakt pozwala niektórym komentatorom sformułować wniosek, że USDA stracił swoje zainteresowanie w utrzymywaniu dużej liczby małych gospodarstw, a jego podstawowym celem jest zapewnienie egzystencji gospodarstwom efektywnym i nowoczesnym poprzez istotną redukcję ogólnej liczby gospodarstw rolnych w USA. ${ }^{24} \mathrm{~W}$ tym sensie aktualne podejście USDA do problemu gospodarstw rodzinnych stanowi całkowite zerwanie $\mathrm{z}$ tradycyjną koncepcją tej instytucji, wywodzącą się od T. Jeffersona, zakładającą, że sektor rolny powinien składać się z jak największej liczby rolniczych jednostek produkcyjnych. ${ }^{25}$

Szeroki sposób definiowania gospodarstw rodzinnych jest również typowy dla opracowywanych w celach statystycznych raportów USDA Economic Research Service $(E R S)$ - wyspecjalizowanej agencji statystycznej działającej w ramach Departamentu Rolnictwa, dostarczającej okresowo informacji o ogólnej sytuacji ekonomicznej gospodarstw rolnych w USA. ${ }^{26} \mathrm{~W}$ raportach tych konsekwentnie definiuje się gospodarstwo rolne (farm) jako jednostkę produkcyjną, z której roczna wartość

S.A. Schneider, Food, Farming and Sustainability. Readings in Agricultural Law, Durham 2011, s. 42-43.

J.B. Wadley, Small Farms..., op. cit., s. 483

H.S. Scher, R.S. Catz, G.H. Mathews, USDA: Agriculture at the Expense of Small Farmers and Farmworkers, „Toledo Law Review" 1976, nr 7, s. 861-862.

J.B. Wadley, Small Farms..., op. cit., s. 484.

Ostatnie raporty opracowane przez tę instytucję pochodzą z lat 2007 i 2010 i są dostępne odpowiednio pod adresami: http://www.ers.usda.gov/publications/eib-economic-information-bulletin/eib24.aspx\#.VEKzl7SWIHY oraz http://www.ers.usda.gov/publications/eib-economic-information-bulletin/eib66.aspx\#.VEKzSLSWIHY 
sprzedaży produktów rolnych wynosi co najmniej 1.000 USD. Z kolei ekonomiczna definicja gospodarstwa rodzinnego ulegała zmianie $w$ ramach poszczególnych edycji tych raportów. W raporcie z 2007 roku pod pojęciem gospodarstwa rodzinnego rozumiano działalność zorganizowaną na bazie własności, spółki lub korporacji rodzinnej, w ramach której nie korzystano z wynajętych managerów. W 2010 roku zrezygnowano $\mathrm{z}$ tej definicji, wprowadzając w jej miejsce nowy sposób ujmowania gospodarstwa rodzinnego, jako działalności gospodarczej, w której większość biznesu spoczywa w rękach osoby prowadzącej to gospodarstwo lub jego małżonka i krewnych, w tym także nie zamieszkujących w miejscu, w którym prowadzona jest ta działalność. Definicje te nie uwzględniają zatem jakichkolwiek kryteriów związanych z wielkością gospodarstwa, metodami prowadzenia działalności rolniczej lub ilością pracy angażowanej przez rodzinę rolniczą w prowadzenie tej działalności, o ile rodzina ta nadal sprawuje funkcje kierownicze. ${ }^{27}$

W konsekwencji zastosowania wyżej wymienionych definicji w 2007 roku do grupy gospodarstw rodzinnych zaliczono w raporcie $98 \%$ wszystkich gospodarstw rolnych w USA, natomiast w 2010 roku $-97,6 \%{ }^{28} \mathrm{~W} 2010$ roku wartość produkcji tak zdefiniowanych gospodarstw rodzinnych wynosiła 82,3\% wartości produkcji wszystkich gospodarstw w USA, a wartość ich mienia pokrywała 93,4\% ogólnego majątku amerykańskich gospodarstw. Tak szerokie ujmowanie gospodarstw rodzinnych w powołanych raportach wymusiło jednak dokonywanie dalszych klasyfikacji w obrębie tej kategorii; raport z 2010 r. wyróżnia np. małe gospodarstwa rodzinne (small family farms), stanowiące $88 \%$ wszystkich gospodarstw w USA, w ramach których roczna wartość sprzedaży brutto wynosi mniej niż 250.000 USD. Małe gospodarstwa rodzinne raport dzieli z kolei na gospodarstwa o charakterze socjalnym (retirement farms), prowadzone przez emerytów, gospodarstwa prowadzone przez osoby utrzymujące się przede wszystkim z pracy poza rolnictwem (residential/lifestyle farms) oraz gospodarstwa prowadzone przez rolników o niskich (poniżej 100.000 USD) lub średnich (100.000 - 249.999 USD) wartościach rocznej sprzedaży brutto (low sales/medium sales). Grupa wielkich gospodarstw rodzinnych (large family farms) obejmuje natomiast gospodarstwa o rocznej wartości sprzedaży brutto powyżej 250.000 USD; w grupie tej wyróżnia się ponadto tzw. bardzo wielkie gospodarstwa rodzinne (very large family farms) o rocznej wartości sprzedaży brutto powyżej 500.000 USD oraz tzw. million-dollar farms o rocznej sprzedaży brutto przekraczającej 1 mln USD. ${ }^{29}$

S.A. Schneider, Food, Farming and Sustainability..., op. cit., s. 43.

Poza zakresem tej definicji pozostały jedynie gospodarstwa prowadzone przez korporacje publiczne lub spółki, w których wspólnicy nie byli ze sobą spokrewnieni, jak również gospodarstwa prowadzone przez wynajętego managera. Por. R. Hoppe, D.E. Banker, Structure and Finances of U.S. Farms. Family Farm Report, 2010 Edition, s. 2.

Wśród 47.600 amerykańskich million-dollar farms aż 86\% stanowią gospodarstwa rodzinne w rozumieniu definicji przyjętej w raporcie z 2010 roku. Gospodarstwa te stanowią zaledwie 2\% wszystkich gospodarstw w USA, 
Wnioski płynące z wymienionych raportów posiadają przede wszystkim ekonomiczny charakter; podkreśla się znaczenie, jakie wielkie gospodarstwa rodzinne i gospodarstwa nierodzinne posiadają dla amerykańskiego rolnictwa pokrywając 4/5 rocznej wartości produkcji rolnej w USA. Zwraca się również uwagę na fakt, że gospodarstwa te są bardziej żywotne ekonomicznie, osiągając zdecydowanie lepsze wyniki finansowe. W podtekście wskazuje się właśnie te gospodarstwa jako zasługujące na publiczne subwencjonowanie. ${ }^{30}$

Przytoczone wyżej definicje gospodarstwa rodzinnego dowodzą, jak niejednolicie może być rozumiane i interpretowane to pojęcie przez różnorodne organy i instytucje oraz doktrynę. W jego zakresie można w USA umieścić obecnie praktycznie każde gospodarstwo, poczynając od minimalnych jednostek, o charakterze socjalnym lub rekreacyjnym, a kończąc na ogromnych przedsiębiorstwach rolnych - million dolar farms. Pojęcie gospodarstwa rodzinnego stanowi zatem dość wygodny szyld, ze względu na długą tradycję otoczony szczególnym społecznym prestiżem, którym można jednak stosunkowo swobodnie manipulować, kierując np. określone regulacje do zupełnie nieporównywalnych gospodarstw, z zachowaniem pozorów, że ich adresatem pozostają gospodarstwa rodzinne. Polityka ta szczególnie dobrze widoczna jest na płaszczyźnie dokumentów pochodzących od USDA i działań podejmowanych przez tę instytucję. $Z$ tego też względu rozważania przeprowadzone w dwóch kolejnych częściach niniejszego opracowania dotyczyć będą ,małych gospodarstw rodzinnych", a więc rolniczych jednostek produkcyjnych, które w raportach ERS sklasyfikowane zostały jako gospodarstwa, w ramach których roczna wartość sprzedaży brutto wynosi mniej niż 250.000 USD.

\section{Znaczenie małych gospodarstw rodzinnych w świetle poglądów amerykańskiej doktryny agrarystycznej}

W amerykańskiej literaturze agrarystycznej odnaleźć można wiele wypowiedzi formułujących argumenty na korzyść małych gospodarstw rodzinnych i w ten sposób uzasadniających konieczność ich szczególnej ochrony. Przy czym charakterystyczne jest, że zagrożenie dla tego typu jednostek produkcyjnych dostrzega się przede wszystkim ze strony wielkich gospodarstw industrialnych (industrial farms). W konsekwencji uzasadnienia dla opieki, którą otoczone być powinny małe gospodarstwa rodzinne szuka się w szczególnego rodzaju wartościach, których dostarcza prowadzenie działalności rolniczej w tego typu jednostkach, a których nie są w stanie zapewnić wielkie gospodarstwa industrialne. Do takich wartości autorzy amerykańscy zaliczają najczęściej uwarunkowania ekologiczne i ekonomiczno-społeczne małych gospodarstw rodzinnych:

ale wartość ich produkcji wynosi aż 53\%. Działają one przede wszystkim w sektorze wołowiny, mleka i produktów mlecznych oraz zbóż. Por. R. Hoppe, D.E. Banker, Structure and Finances of U.S. Farms..., op. cit., s. 10. 
1. W pierwszym rzędzie autorzy amerykańcy dostrzegają niebezpieczeństwo, jakie działalność rolnicza o charakterze industrialnym posiada dla środowiska naturalnego. W tym zakresie krytyce poddawane są przede wszystkim intensywne metody produkcji mięsa, w szczególności wieprzowiny, zakładające utrzymywanie dziesiątków tysięcy zwierząt $\mathrm{w}$ całkowitym zamknięciu na niewielkiej przestrzeni. ${ }^{31}$ Takie metody produkcji skutkują wytwarzaniem znacznej ilości odpadów, ${ }^{32}$ których zagospodarowanie stanowi podstawowy problem dla gospodarstw industrialnych. W konsekwencji, istotna część tych odpadów, zawierających azot, fosfor i inne substancje szkodliwe, takie jak bakterie, hormony, pestycydy i antybiotyki dostaje się do wód, doprowadzając do ich trwałego skażenia. Pomimo podjętych w tym zakresie środków prawnych, ${ }^{33}$ niebezpieczeństwo zanieczyszczenia wody przez odpady zwierzęce uznawane jest w USA za stosunkowo wysokie. ${ }^{34}$ Podobne obawy budzi stężenie chemikaliów, w tym metanu, siarkowodoru, azotu i amoniaku, które odpady zwierzęce wytwarzane $w$ gospodarstwach industrialnych emitują do atmosfery. ${ }^{35}$ Odpadów tych, jako nawozu, nie są bowiem w stanie zagospodarować producenci zbóż, stosujący tańsze i wydajniejsze nawozy sztuczne. ${ }^{36}$

Niezwykle szeroka skala wykorzystania w gospodarstwach industrialnych tego typu nawozów syntetycznych, jak również pestycydów stanowi również zagrożenie dla środowiska naturalnego i zdrowia ludności. ${ }^{37}$ Tytułem przykładu można wskazać, że stosowanie nawozów syntetycznych prowadzi do wyjałowienia gleb, zmuszając tym samym rolników do corocznego zwiększania stopnia nawożenia, a tym

W USA w ciągu ostatnich pięćdziesięciu lat liczba gospodarstw produkujących wieprzowinę zmalała z ponad miliona do zaledwie 65 tys., choć sama produkcja wieprzowiny w tym kraju znacznie się zwiększyła. Gospodarstwa produkujące wieprzowinę metodami industrialnymi zaliczane są do tzw. CAFO (Concentrated Animal Feeding Operation). Por. K. Hassler, T. Balaban, Agricultural Animals and the Law - artykuł pod adresem: http:// www.americanbar.org/newsletter/publications/gp_solo_magazine_home/gp_solo_magazine_index/agriculturalanimals.html

32 Szacuje się, że jedno tylko gospodarstwo, w którym w zamknięciu przebywa 10 tysięcy zwierząt wytwarza tyle odpadów co stutysięczne miasto. Ibidem.

33 Podstawowe standardy jakości wód powierzchniowych oraz zasady ich ochrony określa w USA federalny akt prawny tzw. Clean Water Act. Zgodnie z jego regulacjami, produkcja mięsa metodami zaliczonymi do CAFO wymaga zezwolenia, wydawanego przez Federalną Agencję Ochrony Środowiska (Environmental Protection Agency-EPA). Elementem wniosku o wydanie takiego zezwolenia jest obligatoryjnie tzw. nutrition management plan (NMP), precyzujący zasady zagospodarowania odpadów i nawozu w danym gospodarstwie i wiążący wnioskodawcę po uzyskaniu zezwolenia. Por. M.J. Wender, Goodbye Family Farms..., op. cit., s. 150-151.

Najczęściej wymienianą w literaturze przyczyną tego stanu rzeczy jest wręcz chroniczne niestosowania się CAFO do założeń Clean Water Act, niejednokrotnie polegające wprost na wpuszczaniu odpadów do wód. System grzywien przewidzianych na wypadek tego typu praktyk okazuje się bowiem zbyt mało skuteczny. Por. Informacje zawarte na stronie EPA: http://www.epa.gov

35 Warto w tym miejscu podkreślić, że emisja wyżej opisanych substancji nie podlega federalnemu Clean Air Act; $w$ to miejsce inne akty prawne (Comprehensive Environmental Response, Compensation and Liability Act - CERCLA oraz Community Right-to-Know Act - EPCRA) wprowadzają wymóg, by CAFO raportowały emisję wszelkich niebezpiecznych substancji ponad określoną ilość. Złożenie stosownego raportu należy powtórzyć w roku kolejnym by udokumentować obniżenie poziomu emisji; sama zaś emisja w opisanych warunkach pociąga za sobą sankcje finansowe. Por. K. Hassler, T. Balaban, Agricultural Animals and the Law..., op. cit. M.J. Wender, Goodbye Family Farms..., op. cit., s. 153-154.

37 Szacuje się, że obecnie rolnicy stosują około 119 funtów nawozów syntetycznych na akr ziemi. J.S. Windham, Putting Your Money..., op. cit., s. 19. Powszechne stosowanie tego typu substancji doprowadziło do powstania na niektórych obszarach USA tzw. martwych stref (dead zones), z których największa znajduje się przy ujściu Mississippi do Zatoki Meksykańskiej. 
samym prowokując sytuację, którą można określić mianem błędnego koła. ${ }^{38} \mathrm{Z}$ kolei działanie pestycydów oceniane jest jako szkodliwe dla zdrowia ludzi, w szczególności może ono posiadać skutki rakotwórcze. Ich skuteczność także jest kwestionowana z racji ciągłego pojawiania się organizmów szkodliwych dla roślin (np. insektów), uodpornionych na działanie tych substancji. ${ }^{39}$

Intensywne metody produkcji stosowane $\mathrm{w}$ gospodarstwach industrialnych sa także przyczyną postępującego w USA zjawiska erozji i degradacji gleb. Sprzyja temu ponadto subsydiowana produkcja zbóż na skalę przemysłową, w ramach której rezygnuje się ze stosowania płodozmianu lub czasowego odłogowania gruntu, na rzecz intensywnej produkcji tych gatunków zbóż, do których przysługują dopłaty. Erozja gleb prowadzi z kolei do postępującej emisji dwutlenku węgla do atmosfery. ${ }^{40}$ Ten zaś przyczynia się do zmian klimatycznych, tj. zjawiska, za które również w dużej mierze odpowiedzialne jest rolnictwo. Gospodarstwa industrialne emitują bowiem liczne gazy cieplarniane, jak również konsumują istotne ilości paliw kopalnych. ${ }^{41}$

W tym kontekście działalność prowadzona w małych gospodarstwach rodzinnych uznawana jest za bardziej przyjazną środowisku i bezpieczniejszą dla zdrowia ludzkiego. ${ }^{42}$ Rolnicy prowadzący takie gospodarstwa z reguły zamieszkują bowiem wraz $\mathrm{z}$ rodzinami na ich obszarze lub w ich bezpośrednim sąsiedztwie, mają zatem naturalną skłonność do stosowania metod produkcji bezpiecznych dla zdrowia osób im najbliższych oraz pozwalających na zachowanie wartości produkcyjnych gruntów w celu ich wykorzystania przez kolejne pokolenia. ${ }^{43}$

2. W opinii amerykańskiej doktryny istotne znaczenie małych gospodarstw rodzinnych przejawia się również na płaszczyźnie społeczno-ekonomicznej. Dla wielu Amerykanów gospodarstwa rodzinne stanowią bowiem wartość samą w sobie - korzenie zdecydowanej większości mieszkańców USA sięgają bowiem życia na farmie, pomimo iż współcześnie 98\% amerykańskiego społeczeństwa zamieszkuje na obszarach zurbanizowanych. Utrzymanie gospodarstw rodzinnych - a tym samym szczególnego, rolniczego stylu życia - stanowi zatem jeden z przejawów walki o ochronę spuścizny narodowej i historycznej w USA. ${ }^{44} \mathrm{Z}$ drugiej strony kwestia zachowania gospodarstw rodzinnych posiada także istotne znaczenie dla przy-

38 J.S. Windham, Putting Your Money..., op. cit., s. 20.

39 M.J. Wender, Goodbye Family Farms..., op. cit., s. 157 wskazuje ponadto, że większość pestycydów wbrew swemu przeznaczeniu trafia bezpośrednio do wód, doprowadzając do ich skażenia.

40 W.S. Eubanks, The Sustainable Farm Bill..., op.cit.

41 Badania dowodzą, że produkcja żywności w USA pochłania aż 19\% ogółu paliw kopalnych, ustępując w tym względzie jedynie samochodom i innym pojazdom mechanicznym. Por. M. Pollan, Farmer in Chief, artykuł dostępny pod adresem: http://www.nytimes.com/2008/10/12/magazine/12policy-t.html?pagewanted=all\&_r=0

42 M.J. Wender, Goodbye Family Farms..., op. cit., s. 159.

43 M. Strange, Family Farming..., op. cit., s. 35; C. Hodne, We Whose Future Has Been Stolen, [w:] Is There a Moral Obligation to Save the Family Farm?, G. Comstock (red.), Ames 1987, s. 54.

44 Co ciekawe, jeszcze w 1986 roku ponad połowa ankietowanych Amerykanów stwierdziła, że wolałaby mieszkać na wsi - gdyby to tylko było możliwe. Por.: S.C. Bahls, Preservation of Family Farms..., op. cit., s. 324. 
szłości amerykańskiej wsi. Istnienie tych gospodarstw jest bowiem postrzegane jako szczególne istotne dla zachowania krajobrazu wiejskiego i przekazania go w stanie nienaruszonym przyszłym pokoleniom. ${ }^{45}$

Znaczenie małych gospodarstw rodzinnych jest także istotne z punktu widzenia gospodarczego, choć w tym zakresie ich rola nie jest łatwo dostrzegalna; udział małych gospodarstw w globalnej produkcji żywności w USA jest bowiem stosunkowo niewielki ${ }^{46}$ Niemniej ich egzystencja stanowi niezbędny środek umożliwiający wejście na rynek nowym producentom rolnym, niezdolnym do produkcji żywności na skalę przemysłową, lub też poszerzenie rozmiarów działalności producentom już na tym rynku działającym. Związane jest to przede wszystkim z niższymi kosztami nabycia tego typu gospodarstw, a zatem wykorzystywane w nich środki produkcji rolnej dostępne są również dla osób nie dysponujących znaczącym kapitałem. ${ }^{47}$ Tym samym funkcjonowanie małych gospodarstw rodzinnych pozwala także na zachowanie konkurencji na rynku produktów rolnych. Duża ilość producentów partycypujących w jego mechanizmach eliminuje sytuację, w której jeden lub kilku z nich osiągałoby pozycję dominującą, uzyskując faktyczną możliwość ograniczania konkurencji i dyktowania cen konsumentom. Finalnie zatem istnienie gospodarstw rodzinnych jest korzystne zarówno dla samych producentów, jak i konsumentów wykluczając możliwość powstania oligopoli. ${ }^{48}$

W opinii amerykańskiej doktryny, przetrwanie małych gospodarstw rodzinnych jest też niezbędne dla prawidłowego funkcjonowania całej gospodarki, a nie tylko sektora rolnego. Funkcjonowanie tych gospodarstw zapobiega bowiem depopulacji obszarów wiejskich, a tym samym umożliwia utrzymanie miejsc pracy na tych obszarach, bezpośrednio związanych z bieżącą obsługą gospodarstw rodzinnych. Eliminacja tego typu jednostek produkcyjnych prowadzi nieuchronnie do zamykania wiejskich szkół, przedszkoli, bibliotek, ośrodków zdrowia, a także do likwidacji całego sektora usług i zaopatrzenia dla rolnictwa funkcjonującego na obszarach wiejskich. Tym samym egzystencja małych gospodarstw rodzinnych z jednej strony powiązana jest bezpośrednio z kwestią jakości życia wsi i przetrwania wiejskich wspólnot, z drugiej natomiast zapobiega napięciom społecznym, jakie wywołuje niekontrolowana migracja ludności wiejskiej do miast. ${ }^{49}$

Małe gospodarstwa rodzinne odgrywają także istotną rolę w polityce gospodarowania ziemią w USA. W literaturze podnosi się bowiem, że ta forma gospodarowania ziemią rolną najbliższa jest amerykańskim ideałom, zapewniającym każ-

Wielkie gospodarstwa - stanowiące zaledwie $9 \%$ ogółu gospodarstw w USA - produkują aż $66 \%$ żywności w tym kraju. Por. R. Hoppe, D.E. Banker, Structure and Finances of U.S. Farms..., op. cit., s. 6.

J.B. Wadley, Agriculture and Farm Law..., op. cit., s. 93.

S.C. Bahls, Preservation of Family Farms..., op. cit., s. 325.

J.B. Wadley, The Future of Government Regulation of Agriculture: Biting the Hand that Feeds Us?, „Northern Illinois University Law Review" 1983, z. 3, s. 317. 
demu możliwość samorealizacji poprzez wybraną przez niego formą działalności. Koncentracja ziemi rolnej w ramach wielkich gospodarstw industrialnych prowadzi bowiem do uzyskania przez podmioty je prowadzące kontroli nad jej wykorzystaniem na obszarach wiejskich, a w konsekwencji do narzucenia jedynych możliwych wzorców jej wykorzystania. Zjawisko to stanowi zatem swoiste zaprzeczenie „amerykańskiego snu” uniemożliwiając w praktyce dostęp do ziemi szerokim grupom społecznym. ${ }^{50}$

\section{Aktualne problemy i zagrożenia dla małych gospodarstw rodzinnych w USA}

We współczesnej amerykańskiej literaturze agrarystycznej dostrzega się wiele zagrożeń dla dalszej egzystencji gospodarstw rodzinnych w USA. Całościowa analiza tej skomplikowanej kwestii - ze względu na ograniczone obszary niniejszego opracowania - nie jest oczywiście w tym miejscu możliwa. Niemniej, w ślad za amerykańskimi autorami, można wskazać kilka zasadniczych problemów, z którymi muszą obecnie mierzyć się małe gospodarstwa rodzinne:

1. Ogólna, niestabilna sytuacja ekonomiczna. Oczywistym jest, że działalność rolnicza, podobnie jak każda inna działalność gospodarcza wystawiona jest na ryzyko rynkowe. Rolnictwo amerykańskie również przeżywa w związku z tym okresy hossy i bessy, a poszczególni rolnicy nie mają praktycznie żadnego wpływu na zmieniające się warunki rynkowe. Okresy zapaści gospodarczej dotykają zarówno małe gospodarstwa rodzinne, jak i wielkie gospodarstwa industrialne. Niemniej te pierwsze mają zdecydowanie mniej środków, by przeciwdziałać bieżącym trudnościom ekonomicznym. W dużej mierze problem ten jest konsekwencją stałego - od lat 80 . $\mathrm{XX}$ wieku - obniżania się dochodu netto w małych gospodarstwach rodzinnych. Sytuacja ta zmusza większość rolników prowadzących takie gospodarstwa do poszukiwania dodatkowych źródeł dochodu w sektorach pozarolniczych. ${ }^{51}$

2. Konkurencja ze strony wielkich gospodarstw industrialnych. Charakterystyczną cechą amerykańskiego sektora rolnego jest istnienie ewidentnej dysproporcji pomiędzy liczbą małych gospodarstw rodzinnych a wartością wytwarzanych przez nie produktów rolnych. W świetle badań prowadzonych przez USDA w 2007 roku małe i średnie gospodarstwa rodzinne (o wartości rocznej sprzedaży poniżej 250 tys. USD) - stanowiąc aż 88\% wszystkich gospodarstw rolnych - partycypowały w ogólnej produkcji rolnej w USA jedynie w 16\%. Tym samym aż 84\% wszyst-

50 P. Barnes, Land Reform in America, [w:] Radical Agriculture, R. Merill (red.), New York 1976, s. 30.

51 Aktualne badania wskazują, że zdecydowana większość tzw. małych gospodarstw, tj. gospodarstw o rocznych dochodach ze sprzedaży produktów rolnych poniżej 100.000 USD prowadzona jest przez osoby utrzymujące się także z dochodów o charakterze pozarolniczym, w przede wszystkim z wynagrodzenia za pracę, ale również pomocy społecznej, rent i emerytur, dywidend, odsetek i czynszu. Por.: R. Hoppe, D.E. Banker, Structure and Finances of U.S. Farms..., op. cit., s. V. 
kich produktów rolnych w tym roku wytworzyły wielkie gospodarstwa rolne, w tym głównie gospodarstwa industrialne..$^{52}$ Zarysowany stan rzeczy jest konsekwencją obserwowanego od lat 70. XX wieku zjawiska ciągłego zwiększania się liczby zarówno największych, jak i najmniejszych rolniczych jednostek produkcyjnych. ${ }^{53} \mathrm{Te}$ drugie wszelako skazane są z góry na porażkę w konkurencji o rynki zbytu z wielkimi gospodarstwami industrialnymi. Brak satysfakcjonującego dochodu hamuje z kolei rozwój małych gospodarstw rodzinnych, a nawet zmusza prowadzących je rolników do ograniczania produkcji rolnej lub jej całkowitego zarzucenia na rzecz działalności o nierolniczym charakterze. Ponadto, efektywność gospodarstw industrialnych - rozumiana jako produkcja jak największej ilości żywności przy maksymalnym ograniczeniu wydatków - zachęca instytucje publiczne do subsydiowania tego typu działalności kosztem małych gospodarstw, uznawanych za mniej „efektywne” $\mathrm{W}$ wyżej opisanym sensie. ${ }^{54} \mathrm{~W}$ konsekwencji małe gospodarstwa rodzinne znajdują się w podwójnie trudnej sytuacji: nie mając szans w konkurencji rynkowej z wielkimi gospodarstwami industrialnymi przegrywają z nimi również wyścig o środki publiczne przeznaczone na wsparcie rolnictwa.

3. Presja ze strony obszarów miejskich. Małe gospodarstwa rodzinne w USA najczęściej znajdują się w bezpośredniej okolicy obszarów zurbanizowanych. ${ }^{55}$ Stąd wynikają oczywiste konflikty pomiędzy prowadzącymi je rolnikami a ludnością miejską lub osobami prowadzącymi określoną działalność gospodarczą na obszarach miejskich. Konflikty te posiadają wielowymiarowy charakter. $Z$ jednej strony postępująca urbanizacja i zbliżanie się granic miast do obszarów wiejskich powoduje wzrost wartości ziemi na tych obszarach, a tym samym zwiększanie się obciążeń podatkowych, w szczególności w podatku majątkowym i spadkowym. Sytuacja ta zachęca również do spekulacji ziemią rolną. Ponadto zwiększający się ruch drogowy i napływ ludności miejskiej utrudniają prowadzenie działalności rolniczej; rolnicy muszą wręcz liczyć się z żądaniami zaniechania lub ograniczenia prowadzenia tej działalności, ze względu na dokuczliwość, jaką posiada ona dla przybyszów z miast (nuisance). Perspektywa nieuchronnej urbanizacji powstrzymuje także rolników od dokonywania inwestycji w gospodarstwach, a nawet zachęca ich do wyzbywania się gospodarstw i migracji - albo na bardziej oddalone obszary wiejskie lub do miast. ${ }^{56}$ W tym kontekście istotną rolę odgrywają także tzw. farmland preservation pro-

52 R. Hoppe, D.E. Banker, Structure and Finances of U.S. Farms..., op. cit., s. IV. Autorzy raportu wskazują, że udział małych gospodarstw rodzinnych był jednak istotny w produkcji określonych rodzajów produktów rolnych, w tym przede wszystkim tytoniu, nasion soi i mięsa wołowego. 
grams, a więc programy federalne mające na celu zachowanie obszarów wiejskich i krajobrazu wiejskiego. Niejednokrotnie ich szczegółowe postanowienia realizują bowiem w większym stopniu interesy ludności miejskiej - upatrującej w obszarach wiejskich jedynie miejsce weekendowego odpoczynku i rekreacji - utrudniając lub wręcz uniemożliwiając rolnikom prowadzenie działalności produkcyjnej. ${ }^{57}$

4. Priorytety przyjęte przez instytucje zajmujące się wsparciem rolnictwa, w tym w szczególności USDA. Głównym celem federalnych instytucji zajmujących się wsparciem rolnictwa jest zapewnienie bezpieczeństwa dostaw taniej żywności dla powiększającej się liczby ludności miejskiej. W konsekwencji subwencje i dotacje rządowe kierowane są przede wszystkim do tych producentów, którzy w największym stopniu umożliwiają realizację tego celu, tj. wielkich gospodarstw industrialnych. W tym kontekście, troska o rolników prowadzących małe gospodarstwa rodzinne posiada w polityce instytucji rządowych, w tym w szczególności USDA zdecydowanie mniejsze znaczenie. To skomplikowane zagadnienie zostanie szerzej omówione w dalszej części niniejszego opracowania.

\section{Instrumenty wsparcia gospodarstw rodzinnych w USA}

Wsparcie dla gospodarstw rodzinnych w USA posiada zróżnicowany charakter, jak również świadczone jest przez różne instytucje. Instrumenty tego wsparcia odnaleźć można formalnie zarówno w orzecznictwie amerykańskich sądów, posiadającym istotne znaczenie praktyczne, ze względu na charakterystyczną dla systemu common law prawotwórczą moc orzeczeń sądowych, jak i w legislacji stanowej i federalnej.

1. Orzecznictwo sądów stanowych z lat 80. XX wieku otaczało gospodarstwa rodzinne szczególną ochroną. Zdaniem amerykańskiej doktryny sytuacja taka była skutkiem generalnego kryzysu, jaki w owym czasie dotknął sektor rolny w USA, uderzając głównie $\mathrm{w}$ małe gospodarstwa rodzinne. ${ }^{58} \mathrm{~W}$ konsekwencji, judykatura w owym okresie brała w opiekę rolników prowadzących gospodarstwa rodzinne w sporach z kredytującymi ich instytucjami finansowymi. Sądy podkreślały konieczność ochrony słabszych gospodarczo i niedoświadczonych w operacjach finansowych rolników przyznając im odszkodowania od wyzyskujących te okoliczności banków. ${ }^{59}$

Kolejną płaszczyzną, na której przejawiało się przychylne podejście amerykańskich sądów do gospodarstw rodzinnych była kwestia dalszej egzystencji tych jed-

\footnotetext{
57 J.B. Wadley, Small Farms..., op. cit., s. 493.

58 Por. S.C. Bahls, Termination of Credit for the Farm or Ranch: Theories of Lender Liability, „Montana Law Review” 1987, nr 48, s. 213; idem, Farm and Ranch Credit: Theories of Lender Liability, „William Mitchell Law Review” 1993, nr 19, s. 367. R.B. Schmitt, Farmers, Attacking Landing Practices, Are Taking Banks to Court and Winning, „Wall Street Journal", nr z 6 lipca 1987 roku, s. 6.
} 
nostek produkcyjnych w sytuacji sporu między osobami prowadzącymi takie gospodarstwo. Regulacje stanowe udzielają bowiem kompetencji sądom do interwencji w przypadku zaistnienia sporu pomiędzy osobami sprawującymi funkcje organów korporacyjnych osób prawnych; interwencja ta może wręcz polegać na rozwiązaniu danej osoby prawnej. Ponieważ w świetle rozwiązań amerykańskich gospodarstwa rodzinne również mogą być prowadzone przez osoby prawne, wyżej opisane regulacje znajdują co do zasady zastosowanie także w odniesieniu do takich korporacji. Amerykańskie sądy stanowe wielokrotnie wypowiadały się jednak przeciwko zastosowaniu tego radykalnego rozwiązania, kierując się przede wszystkim dobrem rolniczych jednostek produkcyjnych. W konsekwencji, zamiast orzekania o likwidacji danej osoby prawnej prowadzącej gospodarstwo rodzinne, poszukiwały innych środków umożliwiających rozwiązanie rodzinnego konfliktu. ${ }^{60}$

W literaturze amerykańskiej podkreśla się jednak, że poleganie na judykaturze, jako pewnym sprzymierzeńcu gospodarstw rodzinnych może okazać się zawodne. Dowodzi tego chociażby zmiana linii orzeczniczej, jaka nastąpiła w latach 90. XX wieku w odniesieniu do sporów pomiędzy rolnikami i kredytującymi ich instytucjami finansowymi. Orzecznictwo nie wypracowało zatem jak dotąd trwałych i jednoznacznych zasad ochrony gospodarstw rodzinnych i urzeczywistniających je instrumentów. ${ }^{61}$

2. Instrumenty ochrony gospodarstw rodzinnych wypracowane zostały również w ramach legislacji stanowej. Do najbardziej charakterystycznych należą tzw. AntiCorporate Farming Laws, tj. regulacje stanowe wprowadzające zakaz prowadzenia działalności rolniczej oraz nabywania ziemi rolnej przez korporacje. Aktualnie tego typu ustawy obowiązują w siedmiu stanach USA. ${ }^{62}$ Ich zasadniczym celem jest właśnie ochrona gospodarstw rodzinnych, czego dobitnie dowodzi preambuła do statutu obowiązującego w Minnesocie, zgodnie z którą gospodarstwa rodzinne stanowią „,najbardziej pożądaną formę prowadzenia działalności rolniczej”, a celem statutu jest ,wzmocnienie i promocja stabilności i dobrobytu na wsi, jak również ochrona rodziny". 63

Rozwiązania przyjęte w ramach Anti-Corporate Farming Laws mają swoich zwolenników, dostrzegających konieczność ochrony małych gospodarstw rodzinnych wszelkimi sposobami, ze względu na wartości środowiskowe oraz społeczno- gospodarcze, jakie posiada działalność rolnicza prowadzona w tych jednostkach

60 Por. S.C. Bahls, Judicial Approaches to Resolving Dissension Among Owners of the Family Farm, „Nebraska Law Review" 1994, nr 73, s. 30.

61 S.C. Bahls, Preservation of Family Farms..., op. cit., s. 319.

62 Kansas, Minnesota, Missouri, Nebraska, North Dakota, Oklahoma, i Wisconsin. Por. W. Smart, A.C. Hoberg, Corporate Farming in the Anti-Corporate Farming States, 1989, s. 2-4; M. Chester, Anticorporate Farming Legislation: Constitutionality and Economic Policy, „Drake Journal of Agricultural Law” 2004, nr 9, s. 83. 
produkcyjnych. ${ }^{64}$ Niemniej w literaturze amerykańskiej zdecydowanie dominują poglądy negujące potrzebę odwoływania się do tego typu rozwiązań. Wskazuje się przede wszystkim na ich ograniczone znaczenie praktyczne, ze względu na liczne wyjątki od generalnego zakazu nabywania ziemi rolnej i prowadzenia działalności rolniczej przez korporacje, które stawiają skuteczność tego instrumentu pod znakiem zapytania. ${ }^{65} \mathrm{~W}$ literaturze podnosi się również wątpliwości co do kwestii, czy tego typu regulacje rzeczywiście preferują rolników prowadzących gospodarstwa rodzinne. Ich obowiązywanie prowadzi bowiem do spadku wartości ziemi rolnej, a tym samym uderza w interesy rolników planujących zbycie swoich gruntów. Ponadto zachęcają one koncerny rolnicze do przenoszenia ośrodka swej działalności poza granice stanów, w których takie uregulowania funkcjonują. W konsekwencji prowadzą zatem do odpływu kapitału i utraty rynków zbytu przez miejscowych producentów rolnych. ${ }^{6}$ Problematyczna jest również konstytucyjność tego typu statutów, w szczególności w kontekście drogiej Amerykanom wolności podejmowania działalności gospodarczej. Chociaż w przeszłości sądy uznawały regulacje stanowych Anti-Corporate Farming Laws za zgodne z konstytucją USA, to jednak nowsza linia orzecznicza zdaje się kwestionować ich legalność, czego dowodem może być utrata mocy obowiązującej przez taki statut na podstawie orzeczenia sądowego w Południowej Dakocie (sprawa Hazeltine) ${ }^{67}$

Za nieco bardziej efektywne uznawane są w literaturze pośrednie instrumenty wsparcia gospodarstw rodzinnych w ustawodawstwie stanowym. Do takich rozwiązań należą m.in. statutowe uregulowania sytuacji prawnej stron w ramach stosunku kontraktacji, zmierzające do ograniczenia ekonomicznej dysproporcji pomiędzy kontraktującym a producentem rolnym. Regulacje te wprowadzają np. obowiązkową mediację lub arbitraż na wypadek wystąpienia sporu, dłuższe terminy wypowiedzenia umowy przez kontraktującego, jak również generalny zakaz stosowania nieuczciwych praktyk. ${ }^{68}$ Podobne znaczenie mają stanowe akty prawne ograniczające przeznaczenie gruntów rolnych na cele nierolne (farmland preservation statutes) oraz statuty chroniące rolników przed żąaniami właścicieli sąsiednich nieruchomości ograniczenia lub zaprzestania prowadzenia przez nich działalności rolniczej - dokuczliwej z punktu widzenia stosunków sąsiedzkich (tzw. right to farm statutes) ${ }^{69} \mathrm{~W}$ literaturze uznaje się, że powołane rozwiązania stanowe lepiej chronią in-

J. Stout, The Missouri Anti-Corporate Farming Act: Reconciling the Interests of the Independent Farmer and the Corporate Farm, „University of Missouri-Kansas City Law Review” 1996, nr 64, s. 835.

Spod tego zakazu wyłączone są np. takie jednostki organizacyjne, w których kierownictwo spoczywa w rękach osób powiązanych więzami rodzinnymi. Ponadto statuty dopuszczają możliwość ustanawiania zabezpieczeń na nieruchomościach rolnych, która to praktyka często prowadzi do ich przejmowania przez kredytujące instytucje. Por. R.F. Prim, Saving the Family Farm..., op. cit., s. 208-212. S.C. Bahls, Preservation of Family Farms..., op. cit., s. 314; R.F. Prim, Saving the Family Farm..., op. cit., s. 220. Więcej na ten temat: M. Chester, Anticorporate Farming Legislation..., op. cit., s. 102-104; R.F. Prim, Saving the Family Farm..., op. cit., s. 215.

68 N.D. Hamilton, State Regulation of Agricultural Production Contracts, „The University of Memphis Law Review” 1995, nr 25, s. 1051 i n.

69 S.C. Bahls, Preservation of Family Farms..., op. cit., s. 316 
teresy rolników prowadzących gospodarstwa rodzinne niż Anti-Corporate Farming Laws, choć amerykańscy autorzy zauważają także, że jakakolwiek zbyt dotkliwa ochrona gospodarstw rodzinnych na poziomie stanowym zachęca przedsiębiorców dyskryminowanych takimi regulacjami do przenoszenia swojej działalności do innych stanów, a tym samym ogranicza atrakcyjność ekonomiczną stanu stosującego takie rozwiązania. $^{70}$

3. Na płaszczyźnie regulacji federalnych wsparcie gospodarstw rodzinnych polega między innymi na stosowaniu ulg i zwolnień w zakresie prawa podatkowego i upadłościowego. ${ }^{71}$ Największe znaczenie dla egzystencji tych gospodarstw posiadają jednak subwencje udzielane na podstawie federalnych programów wsparcia, administrowanych przez USDA. Prawną podstawę dla wdrażania tych programów stanowią Farm Bills akty prawne uchwalane zwykle co 5 lat przez Kongres, określające politykę rolną i żywnościową władz federalnych USA na czas obowiązywania danego Farm Bill. ${ }^{72}$ Programy te zaliczane są do dwóch grup:

a) programy skierowane na wsparcie produkcji rolnej (commodity related payments) - przewidujące różnego rodzaju płatności bezpośrednie oraz dopłaty do cen produktów rolnych (direct payments, countercyclical payments, loan deficiency payments), jak również płatności klęskowe (disaster payments); ich celem jest wsparcie dochodów rolniczych oraz stabilizacja produkcji i cen produktów rolnych; przyznawane są rolnikom wytwarzającym aktualnie lub też w przeszłości określone produkty rolne, w tym w szczególności zboża, bawełnę i mleko.

b) programy skierowane na zachowanie gruntów rolnych (conservation programs) przewidujące zarówno płatności do gruntów wyłączonych z produkcji (tzw. payments from land retirement programs), których celem jest trwałe lub czasowe (minimum 10-letnie) odłogowanie gruntów szczególnie wrażliwych ekologicznie, jak również płatności do gruntów wykorzystywanych rolniczo (tzw. payments from working-land programs), za pomocą których subwencjonowani są rolnicy decydujący się na stosowanie szczególnie pożądanych praktyk z punktu widzenia ochrony środowiska. ${ }^{73}$

Ibidem, s. 318.

Ustawodawca amerykański nie kreuje bowiem jakichkolwiek szczególnych regulacji o charakterze prywatnoprawnym, które miałyby sprzyjać tworzeniu lub utrzymaniu tych jednostek produkcyjnych. W szczególności obrót inter vivos i mortis causa gruntami wchodzącymi w skład tych jednostek produkcyjnych poddany został regułom ogólnym; w USA nie istnieje szczególny reżim dotyczący obrotu gruntami rolnymi lub gospodarstwami rolnymi. Por. J.B. Wadley, Agriculture and Farm Law..., op. cit., s. 10.

Na podstawie do niedawna realizowanego Food, Conservation and Energy Act (Farm Bill 2008) na różne programy wdrażane przez USDA rozdysponowano ponad 307 miliardów dolarów. Nowy Farm Bill z 2014 roku przewiduje wydatkowanie w bieżącym okresie programowania (tj. do 2018 roku) ponad 954 miliardów dolarów. Por. M.J. Wender, Goodbye Family Farms..., op. cit., s. 160-161.

Płatności do gruntów odłogowanych przyznawane są na podstawie różnych programów, takich jak np. Conservation Reserve Program (CRP) oraz Conservation Reserve Enhancement Program (CREP), na podstawie których zachęca się rolników do wyłączenia uprawianych gruntów z produkcji z przeznaczeniem ich na łąki lub pastwiska, jak również Wetlands Reserve Program (WRP) oraz Farmable Wetlands Reserve Program (FWP) prze- 
Spośród wymienionych płatności zdecydowanie więcej środków finansowych (w sumie około $75 \%$ wszystkich funduszy federalnych przeznaczonych na wsparcie rolnictwa) absorbują płatności zaliczające się do pierwszej z wyżej opisanych grup, tj. wynikające z programów skierowanych na wsparcie produkcji rolnej. Cechą charakterystyczną amerykańskiego systemu subwencjonowania rolnictwa jest jednak okoliczność, że płatności te trafiają przede wszystkim do gospodarstw o dużych rozmiarach, zaliczonych w raporcie USDA Economic Research Service (ERS) z 2010 roku do wielkich lub bardzo wielkich gospodarstw rodzinnych oraz do gospodarstw nierodzinnych. W 2007 roku do takich gospodarstw trafiło aż 76\% wszystkich płatności skierowanych na wsparcie produkcji rolnej. Wielkie gospodarstwa rolne są również głównymi beneficjentami płatności do gruntów wykorzystywanych rolniczo przyznawanych na podstawie programów skierowanych na zachowanie gruntów rolnych, absorbując około 3/5 ogółu tych płatności.

Z kolei płatności do gruntów wyłączonych z produkcji trafiają przede wszystkim do najmniejszych gospodarstw zaliczonych w raporcie USDA Economic Research Service $(E R S)$ z 2010 roku do kategorii prowadzonych przez emerytów gospodarstw o charakterze socjalnym (retirement farms), gospodarstw prowadzonych przez osoby utrzymujące się przede wszystkim z pracy poza rolnictwem (residential/lifestyle farms) oraz gospodarstw prowadzonych przez rolników o niskich (poniżej 100.000 USD) wartościach rocznej sprzedaży brutto (low sales). Tego typu gospodarstwa absorbują aż $73 \%$ tych płatności, co związane jest z faktem, iż prowadzące je osoby z reguły większość środków do życia czerpią z pracy poza rolnictwem, a płatności wynikające z tych programów traktują jako dodatkowe źródło dochodu, nie wymagające nakładów środków finansowych i czasu pracy, niezbędnych dla prowadzenia efektywnej działalności rolniczej. ${ }^{74}$

Pomimo zaangażowania tak istotnych federalnych środków finansowych w subwencjonowanie rolnictwa oraz opracowania zróżnicowanych programów wsparcia gospodarstw rolnych w 2010 roku jedynie 39\% ogółu tych jednostek produkcyjnych skorzystało z jakiejkolwiek formy wsparcia co oznacza, że zdecydowanej większości gospodarstw rolnych w USA nie przyznano żadnych płatności wynikających z programów federalnych. ${ }^{75}$

widujące wsparcie dla rolników utrzymujących bagna na swych gruntach. Z kolei płatności do gruntów wykorzystywanych rolniczo przyznawane są na podstawie takich programów, jak: Environmental Quality Incentives Program (EQIP) oraz Conservation Security Program (CSP) zmierzających do udzielania finansowego i technicznego wsparcia rolnikom dokonującym w swoich gospodarstwach określonych zabiegów mających na celu ochronę środowiska. W 2007 roku land-retirement payments stanowiły 78\% wszystkich płatności przyznawanych na podstawie conservation programs, przy czym same tylko płatności przyznawane na podstawie CRP stanowiły $74 \%$ płatności wynikających z conservation programs. Por. R. Hoppe, D.E. Banker, Structure and Finances of U.S. Farms. Family Farm Report, 2010 Edition, s. 33-34.

Por. R. Hoppe, D.E. Banker, Structure and Finances of U.S. Farms..., op. cit., s. 36.

Ibidem, s. V. 


\section{Uwagi końcowe}

Analiza danych statystycznych przytoczonych w poprzednim rozdziale skłania niektórych przedstawicieli amerykańskiej doktryny do wysunięcia wniosku, że na płaszczyźnie programów wsparcia rolnictwa instytucje federalne, w tym w szczególności USDA zdecydowanie preferują wielkie gospodarstwa, przywiązując tylko nieznaczną uwagę do sytuacji małych gospodarstw rodzinnych. ${ }^{76}$ Dowodów na poparcie tej tezy dostarczają także rozwiązania przyjęte w ramach najważniejszych amerykańskich regulacjach prawno-rolnych ostatnich lat. Rządowe wsparcie na gruncie realizowanego do niedawna Farm Bill z 2008 roku adresowane było przede wszystkim do dużych gospodarstw, prowadzonych najczęściej przez korporacje. $\mathrm{Z}$ systemu subwencjonowania wyłączone były gospodarstwa najmniejsze, $\mathrm{tj}$. o powierzchni poniżej 10 akrów (a więc najczęściej gospodarstwa o charakterze rodzinnym). Formalnie do wsparcia rządowego nie kwalifikowali się także rolnicy najbogatsi, tj. osiągający roczny dochód przekraczający 750 tys. USD lub 1,5 $\mathrm{mln}$ USD w przypadku małżeństwa. Taki pułap rocznego dochodu wykluczający możliwość ubiegania się o rządowe wsparcie w literaturze agrarystycznej określany był jednak jako nieracjonalnie wysoki. ${ }^{77}$

Również postanowienia obecnie obowiązującego Farm Bill, uchwalonego 29 stycznia 2014 roku i precyzującego instrumenty wsparcia amerykańskiego rolnictwa na lata 2014-2018 oceniane są jako generalnie dyskryminujące małe gospodarstwa rodzinne. Imponujące środki finansowe przeznaczone na subwencjonowanie rolnictwa w bieżącym okresie (około 954 miliardów dolarów) w założeniu ponownie trafić mają do największych gospodarstw w kraju, w ramach płatności przeznaczonych na wsparcie produkcji rolnej oraz subsydiowanego systemu ubezpieczeń płodów rolnych (crop insurance) ${ }^{78}$

W kontekście powyższych faktów aktualną sytuację gospodarstw rodzinnych w USA określić można jako paradoksalną. Pomimo społecznego prestiżu, jakim otoczona jest ta instytucja oraz znaczenia, jakie przypisuje się jej w literaturze agrarystycznej, zakres wsparcia udzielanego gospodarstwom rodzinnym jest stosunkowo ograniczony. Instrumenty pomocy przewidziane legislacją stanową mają bowiem

76 W opinii amerykańskich autorów sytuacja ta wynika z polityki realizowanej przez USDA zakładającej konieczność konsolidacji gospodarstw rolnych w celu zwiększenia produkcji i zapewnienia tym samym bezpieczeństwa dostaw żywności dla zwiększającej się systematycznie liczby ludności miejskiej. W tym kontekście pod adresem USDA formułowane są zarzuty, iż instytucja ta uwzględnia jedynie ekonomiczny aspekt zjawiska, jakim jest rolnictwo, zaniedbując jego pozostałe funkcje, realizowane przede wszystkim przez gospodarstwa rodzinne. Traktując działalność rolniczą wyłącznie w kategoriach ekonomicznych, a rolników uznając jedynie za przedsiębiorców uczestniczących w zwykłej grze rynkowej, USDA paradoksalnie realizuje interesy populacji miejskiej, zainteresowanej przede wszystkim w niskich cenach żywności oraz dostępności terenów wiejskich dla potrzeb rozbudowujących się miast. Por. H.S. Scher, R.S. Catz, G.H. Mathews, USDA: Agriculture at the Expense of Small Farmers and Farmworkers..., op. cit., s. 495; J.B. Wadley, Small Farms..., op. cit., s. 495.

77 M.J. Wender, Goodbye Family Farms..., op. cit., s. 161.

78 Por. L. Reitzig, Farm Bill 2014 or "The Destruction of Small Family Farms" - artykuł dostępny pod adresem: http://nourishingliberty.com/farm-bill-2014-just-how-bad-is-it/\#sthash.AJ4nnfkQ.dpuf 
charakter raczej symboliczny, natomiast ze środków federalnych subwencjonowana jest przede wszystkim działalność agrobiznesu. ${ }^{79} \mathrm{~W}$ dużej mierze sytuacja ta jest zresztą konsekwencją sygnalizowanego braku precyzyjnej definicji gospodarstwa rodzinnego, jako preferowanej formy działalności rolniczej. W obecnej rzeczywistości instytucje federalne - swobodnie definiując gospodarstwa tego typu - dotują bowiem największe i najbogatsze jednostki produkcyjne, umieszczając je w kategorii gospodarstw rodzinnych.

Opisana sytuacja zachęca niektórych przedstawicieli doktryny do formułowania postulatów o konieczności głębokiej reformy systemu subwencjonowania rolnictwa w USA, tak by w większym zakresie korzystały z niego także małe gospodarstwa rodzinne. Najbardziej radykalna propozycja zakłada całkowitą likwidację jakichkolwiek form wsparcia i stworzenie w konsekwencji rynku produktów rolnych wolnego od publicznych subsydiów. ${ }^{80} \mathrm{~W}$ myśl bardziej umiarkowanych postulatów subwencje należałoby utrzymać, niemniej kierować je do rolników stosujących zrównoważone metody produkcji, umożliwiając im w ten sposób obniżenie cen za wytwarzane przez nich produkty, które stałyby się bardziej konkurencyjne względem produktów wytwarzanych metodami industrialnymi. ${ }^{81}$ Jeszcze inne propozycje zakładają wprowadzenie zupełnie nowych systemów pomocowych, polegających np. na zastąpieniu dotychczasowych subsydiów programami wsparcia dochodów rolniczych za pośrednictwem kredytów udzielanych przez instytucje federalne, których zwrot w przypadku nagłego załamania cen rynkowych na produkty rolne następowałby poprzez przekazanie tych produktów przez zadłużonych rolników do rezerwy rządowej. ${ }^{82} \mathrm{~W}$ konsekwencji, zdaniem niektórych autorów, za pomocą radykalnej reformy systemu subwencjonowania można by osiągnąć zasadniczy cel, jakim jest rolnictwo zrównoważone, sprzyjające ochronie środowiska i zdrowia ludności, jak również jakości życia na wsi, którego nieodłącznym elementem są gospodarstwa rodzinne. ${ }^{83}$

Należy wszelako podkreślić, że pogląd o konieczności ochrony małych gospodarstw rodzinnych nie jest w amerykańskiej doktrynie agrarystycznej przyjmowany jednomyślnie; niektórzy autorzy wprost kwestionują potrzebę szczególnej opieki nad gospodarstwami rodzinnymi, wskazując, że przywiązanie do tej instytucji ma obecnie w USA raczej jedynie sentymentalny charakter, a tendencja do koncentracji jest procesem nieodwracalnym i jedynym uzasadnionym ekonomicznie. Wskazują oni ponadto na ograniczone znaczenie gospodarstw rodzinnych dla ochrony środo-

Obserwacji tej nie zmienia okoliczność, że Farm Bills z 2008 i 2014 roku zawierają także regulacje, traktowane jako sprzyjające małym gospodarstwom rodzinnym, przewidując zwiększenie środków na programy skierowane na zachowanie gruntów rolnych (conservation programs) oraz na promocję żywności ekologicznej (organic food). Por. M.J. Wender, Goodbye Family Farms..., op. cit., s. 161-162. W.S. Eubanks, The Sustainable Farm Bill..., op. cit.

M.J. Wender, Goodbye Family Farms..., op. cit., s. 163. Ibidem, s. 164.

W.S. Eubanks, The Sustainable Farm Bill..., op. cit. 
wiska naturalnego, podnosząc, że w rzeczywistości rolnicy prowadzący takie jednostki - ze względu na postępującą standaryzację i uniformizację produkcji - stosują te same metody produkcyjne co wielkie gospodarstwa industrialne. ${ }^{84}$

Ta ostatnia uwaga pozwala dostrzec, że znaczenie małych gospodarstw rodzinnych może być jednak kwestionowane i to nie tylko przez instytucje federalne, ale samych przedstawicieli doktryny agrarystycznej. W tym kontekście przyszłość małych gospodarstw rodzinnych w USA należy określić jako co najmniej niepewną. 
FAMILY FARMS IN THE USA - THEIR STATUS, IMPORTANCE AND CURRENT PROBLEMS

Keywords: family farm, small family farm, American agriculture

The article discusses a wide range of issues concerning an American conception of the family farm, taking into account its historical genesis and current approach of US institutions and American doctrine. In this context, the author aims to verify traditional argument, that family farms constitute the basis of American agriculture.

An attempt to achieve above-mentioned purpose of the paper affects strongly its construction. In the first part of the article, the Author describes American notion of the "family farm" and its numerous definitions within US state and federal law, as well as doctrinal statements. The second part of the paper is devoted to the importance of small family farms to the American economy and to the role, which these units actually play in the American agriculture. Furthermore, the Author makes an attempt to indicate the most important problems that currently face small family farms in the US. Finally, in the last part of the article, the Author tries to describe the methods of family farms support, which is provided by different public entities - first of all United States Department of Agriculture, but also state legislatures and court jurisdiction (case-law). 